\title{
KARAKTERISTIK KAIN ATBM DOBBY HASIL PENGEMBANGAN MOTIF BATIK KHAS KOTA BANDUNG SEBAGAI MOTIF TENUN IKAT UNTUK KAIN KEMEJA
}

\author{
CHARACTERISTIC OF DOBBY HANDLOOM FABRIC DEVELOPMENT \\ OUTCOME OF THE TYPICAL BANDUNG CITY'S MOTIF AS IKAT \\ WEAVING MOTIF FOR SHIRT FABRIC
}

\author{
Dermawati Suantara, Yusniar Siregar, Moekarto Moeliono \\ Balai Besar Tekstil, Jalan Jenderal Ahmad Yani No. 390 Bandung \\ E-mail: texirdti@bdg.centrin.net.id
}

Tanggal diterima: 22 Juli 2016, direvisi: 2 November 2016, disetujui terbit: 2 November 2016

\begin{abstract}
ABSTRAK
Penelitian ini bertujuan untuk membuat kain tenun ATBM dobby dan kombinasi ikat dari motif batik tradisional yaitu motif khas Kota Bandung yang dikembangkan dan disesuaikan dengan trend warna 2015. Hasil pengujian pada kain ATBM menunjukkan bahwa kekuatan tarik kain arah lusi adalah 26,5 $\mathrm{kg}$ dan arah pakan 29,4 kg. Untuk kekuatan sobek, arah lusi adalah 4,8 kg dan arah pakan adalah 4,2 kg. Nilai kekuatan tarik dan kekuatan sobek, kain tenun ATBM dobby ini telah memenuhi standar SNI 0051-2008. Dari hasil uji kain secara kimia, tahan luntur warna terhadap pencucian $40^{\circ} \mathrm{C}$ adalah $4-5$; tahan keringat asam dan basa 4-5; tahan gosok kering 4; tahan gosok basah 2-3. Hasil pengembangan motif Jawa Barat dan kombinasi tenun ikat menggunakan ATBM dobby ini diharapkan dapat memberikan kontribusi pada IKM tenun sebagai bentuk eksplorasi desain kain tenun modern.
\end{abstract}

Kata kunci : kain tenun, dobby, ikat, motif, tradisional.

ABSTRACT

This research is aimed to make dobby handloom woven fabric and ikat combination from traditional batik motifs i.e. The typical Bandung city's motif that was developed and adapted to the color trends in 2015. The test results showed that handloom woven fabric tensile strength was $26.5 \mathrm{~kg}$ in warp direction and $29.4 \mathrm{~kg}$ in weft direction. For the tear strength, the warp direction was $4.8 \mathrm{~kg}$ and in the weft direction was $4.2 \mathrm{~kg}$. Values of tensile strength and tear strength dobby handloom woven fabric is in compliance with ISO 0051-2008 standards. From the test results of chemical fabric, color fastness to washing $40{ }^{\circ} \mathrm{C}$ was 4-5; sweat acid and alkaline resistant was 4-5; dry scrubbing resistant was 4; and wet scrubbing resistant was 2-3. The result of the development of West Java design andikat combination using dobby handloom is expected to contribute to the SME weaving as a figuration of modern woven fabric design exploration.

Keywords : woven fabric, dobby, ikat, motif, traditional.

\section{PENDAHULUAN}

Ragam motif batik Jawa Barat umumnya terinspirasi dari keindahan dan kekayaan alam yang subur di tatar Priangan yang digambarkan secara naturalistik. Pengaruh lokal dan berbagai pengaruh dari budaya asing seperti Cina, Hindu, dan Islam tampak pada batik dengan motif angkin (corak anyaman), banji, kawung, dan lar. Namun banyak pula jenis-jenis flora yang ada di daerah Sunda atau Priangan dijadikan inspirasi oleh para seniman dan perajin dalam menciptakan karyanya. ${ }^{1}$
Motifbatik yang unik, kreatif, dan inovatif merupakan motif batik kreasi baru berbasis seni budaya lokal dan lingkungan alam sangat diminati oleh masyarakat. Motif batik tersebut disusun menjadi pola batik yang siap diwujudkan menjadi batik dengan bahan kain tenun. ${ }^{2,3}$

Industri tenun masih potensial untuk dikembangkan karena keragaman budaya dan kekhasan seni hias untuk diaplikasikan ke produk tenundapat dilakukan dengan teknologi yang sederhana. Selain itu teknologi digital telah menjadi sarana untuk menampung ekspresi seni 
masyarakat. Pengembangan batik secara modern sudah memasuki ranah kolaborasi dengan ilmu dan teknologi dengan cara menghasilkan varian baru melalui pengembangan unsur desain di dalamnya., ${ }^{4,5}$

Kain tradisional terdiri dari unsur-unsur desain yang salah satunya dinamakan motif (ragam hias, corak, patron). Motif adalah kerangka gambar yang mewujudkan tema, citra, dan kesan secara menyeluruh sebagai kesatuan utuh yang terdiri atas susunan titik, garis, bidang, tesktur dan warna yang khas. ${ }^{6,7}$ Motif yang dikembangkan dalam penelitian ini adalah salah satu dari motif geometris yaitu motif kawung. Motif geometris menggunakan unsur-unsur rupa seperti garis dan bidang yang pada umumnya bersifat abstrak, artinya bentuknya tak dapat dikenali sebagai bentuk objek-objek tertentu. Motif geometris berkembang dari bentuk titik, garis, atau bidang yang berulang, dari yang sederhana sampai dengan pola yang rumit. Pada kebanyakan motif ornamen geometris kurang mengandung nilai simbolis. Motif geometris abstrak murni banyak terdapat pada pola anyam, pengulangan bidang lingkaran atau segitiga, dan lain-lain. ${ }^{8,9}$

Motif kawung terjadi dari bentuk-bentuk lingkaran yang saling berpotongan berjajar ke kiri atau ke kanan dan ke bawah atau atas. Istilah kawung dalam bahasa Sunda berarti buah aren (enau). Motif kawung banyak terdapat pada batik. Motif kawung bermakna keinginan dan usaha yang keras akan selalu membuahkan hasil, seperti rejekinya berlipat ganda. Orang yang bekerja keras pasti akan menuai hasil, walaupun kadang harus memakan waktu yang lama. ${ }^{10}$ Motif binari kawung mulai ada sejak zaman sebelum kemerdekaan, batik Bandung dibuat oleh para perajin di sekitar pinggiran sungai Cikapundung. Namun pada saat ini peninggalannya sudah tidak tersisa. Saat ini batik Bandung berkembang dan lebih mengedepankan desain kontemporer dan modern, mengingat Bandung sebagai kota kreatif. Namun ada pula beberapa motif kedaerahan yang pernah dikembangkan. Ada beberapa daerah pengembangan batik Bandung, diantaranya berada di daerah Cigadung, yakni daerah dekat Taman Makam Pahlawan Cikutra. Di daerah ini ada beberapa tokoh yang berkiprah dalam pengembangan batik Jawa Barat. Adapula industri kerajinan batik yang berada di daerah Sarijadi dan Bojong Koneng. ${ }^{11}$ Ornamen batik kawung dapat dilihat pada Gambar 1.

Motif Jalak Harupat adalah sebutan untuk sejenis ayam jantan dalam bahasa Sunda. Ayam tersebut dimitoskan sebagai ayam yang kuat, pemberani, nyaring saat berkokok, selalu menang saat diadu. Sifatnya yang demikian membuatnya dijadikan julukan bagi seorang pemberani. Sebagai ornamen Nusantara, pada umumnya motif jago melambangkan kekuatan, keberanian, dan juga kesuburan. Bentuk ayam jantan yang indah dan gagah merupakan motif hias yang menambah nilai estetis pada kain tenun dan batik, seperti terlihat pada Gambar 2.

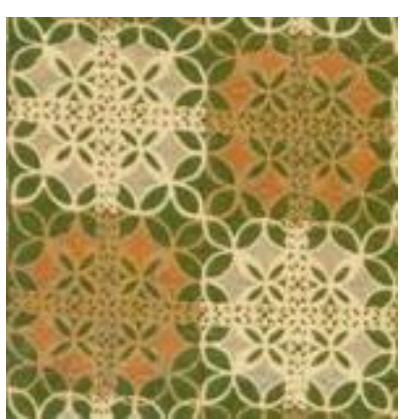

Gambar 1. Ornamen binari kawung

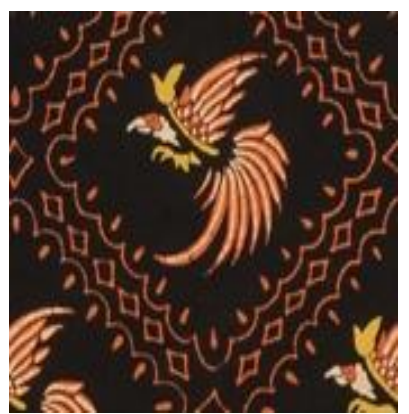

Gambar 2. Ornamen jalak harupat

Kain tenun nusantara yang terkenal adalah yang digunakan pada kain dengan ragam hias ikat, dikenal juga dengan nama kain tenun ikat. Corak kain dibuat dengan cara mengikat bagianbagian tertentu dari benang hingga warna tidak menyerap pada saat pencelupan berlangsung. Bagian yang tidak terwarnai ini akan membentuk corak pada kain setelah benang ditenun. Corak yang dibuat pada kelompok benang searah lebar kain (pakan) disebut tenun ikat pakan. Corak yang dibuat pada kelompok benang lusi disebut tenun ikatlusi. Paduan dari keduanya disebut tenun ikat ganda. Pada tenun ikat pakan, benang yang diikat merupakan kumpulan benang pakan yang searah dengan lebar kain. Setelah benang diikat, dicelup dan dikeringkan, benang kemudian digulung pada pale. ${ }^{13,14}$

Tren warna pada tahun 2015 adalah warna-warna lembut, warna dingin dan warna alam yang netral, seperti warna-warna dibawah ini: ${ }^{15}$ 


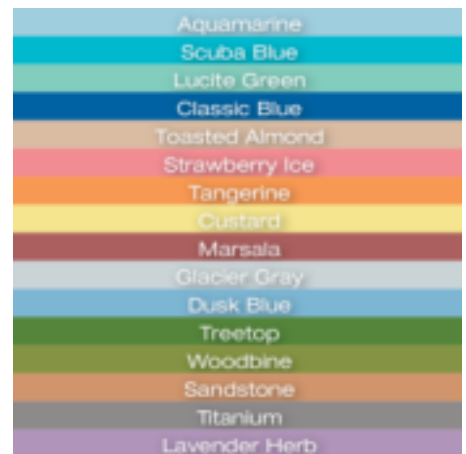

Gambar 3. Skema trend warna 2015 untuk fashion

Penelitian ini bertujuan untuk membuat kain tenun ATBM dobby dengan desain motif batik tradisonal yang dikembangkan dan disesuaikan dengan trend warna 2015. Hal tersebut perlu dilakukan karena penelitian mengenai pengembangan motif khususnya motif batikkhas Jawa Barat masih terbatas, hal ini dalam usaha menyesuaikan dengan perkembangan jaman yang menuntut adanya inovasi di dalam mengembangkan motif batik tradisional ke dalam kain tenun ATBM dobby. Hasil pengembangan desain motif batik tradisional dengan menggunakan ATBM dobby inidiharapkan dapat memberikan kontribusi pada IKM tenun sebagai bentuk eksplorasi desain kain tenun modern.

\section{METODE}

Diagram alir penelitian adalah sebagai berikut :

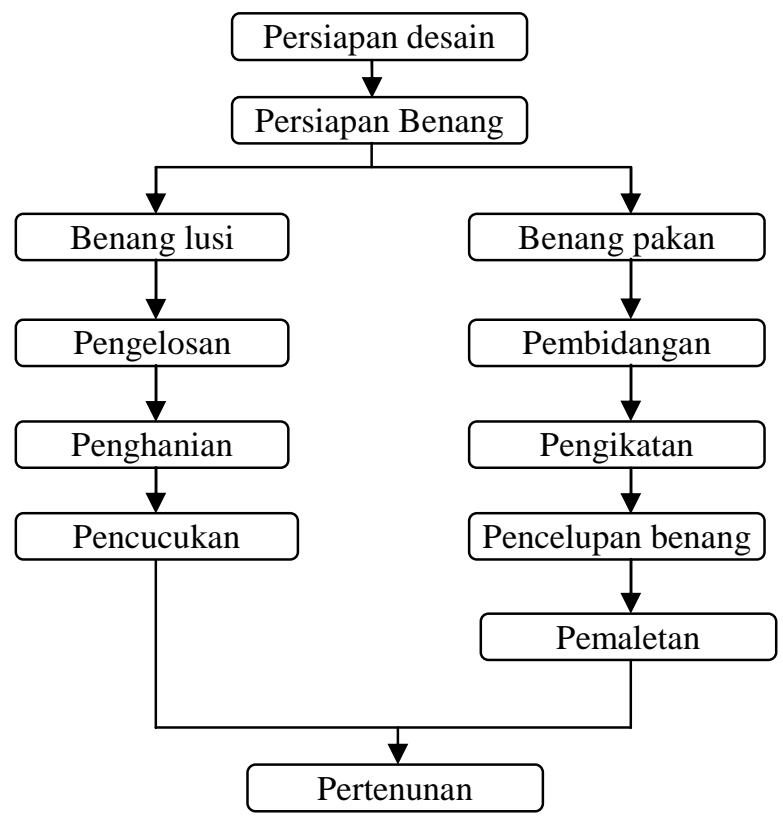

Gambar 4. Diagram alir penelitian

\section{Bahan dan Peralatan}

Bahan baku dalam penelitian ini adalah benang kapas, zat warna reaktif (procion blue), zat pembantu sodium sulfat dan matexil, serta zat pengental manutex. Peralatan yang digunakan meliputi alat pengelosan, alat hani, alat pemaletan, dan ATBM dobby.

\section{Proses Persiapan Desain}

Tahap awal dalam perencanaan dan pembuatan desain adalah menentukan desain komposisi warna yang akan digunakan pada benang lusi dan benang pakan kain tenun ATBM dobby, sesuai dengan trend warna 2015 untuk fashion. Setelah menentukan komposisi warna, peneliti memilih 2 motif batik Sunda khususnya batik khas Kota Bandung yang akan dikembangkan dan diaplikasikan pada kain tenun ATBM dobby yaitu motif binari kawung dan jalak harupat.

Dalam proses persiapan, kebutuhan benang lusi dan pakan dihitung sesuai dengan kebutuhan, seperti lebar kain, kerapatan benang yang berkaitan dengan no sisir. Berikut ini adalah perhitungan kebutuhan benang pada proses pembuatan kain tenun ATBM dobby-ikat yang akan dibuat.

Rumus perhitungan kebutuhan benang lusi, diberikan menurut persamaan sebagai berikut:

$$
\frac{\text { lebar kain }}{\text { lebar/'inch }} \text { x no.sisir }+5 \% \text {....(1) }
$$

Kebutuhan benang lusi yang dihitung menurut persamaan (1), adalah sebagai berikut:

$$
\frac{115 \mathrm{~cm}}{2,54} \times 80+5 \%=3800 \text { helai }
$$

1 Benang Lusi

2 Warna benang lusi

3 Tetal Lusi

4 No sisir

5 Jumlah total benang lusi : 3800 helai

Berdasarkan desain pada Gambar 5, kebutuhan benang lusi diatas, diuraikan sesuai dengan warna benang adalah sebagai berikut:

1. Benang lusi warna biru tua: 497 helai benang

2. Benang lusi warna biru tosca: 2902 helai benang

3. Benang lusi warna hijau tosca: 401 helai benang 


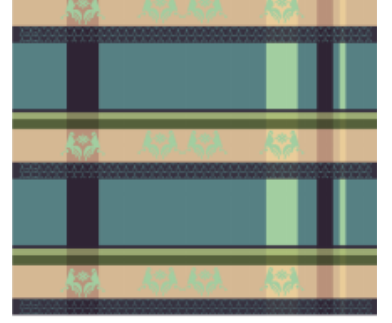

Gambar 5. Rancangan kebutuhan benang lusi

\section{Proses Tenun}

Sebelum melakukan persiapan pertenunan, rancangan motif pada kain tenun disusun menjadi rencana cucukan dan rencana susunan paku dobby yang dibuat menggunakan perangkat lunak $D B$-Weave, seperti terlihat pada Gambar 4.
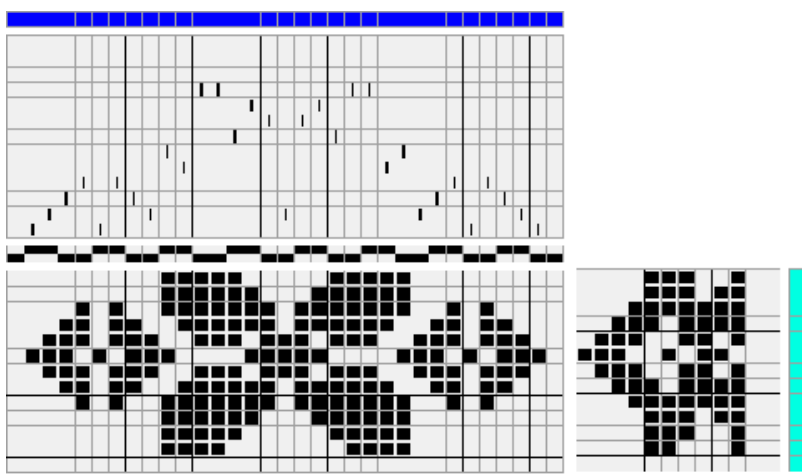

Gambar 6.Rencana tenun motif binari kawung

\section{Pengujian}

Pengujian yang dilakukan berdasarkan pada SNI 0051-2008, antara lain adalah uji kekuatan tarik, uji kekuatan sobek, tahan luntur warna dan tahan gosok.

\section{HASIL DAN PEMBAHASAN}

Berikut ini adalah hasil dari pengembangan ornamen batik kota Bandung ke dalam ornamen kain tenun ATBM dobby-ikat pakan:

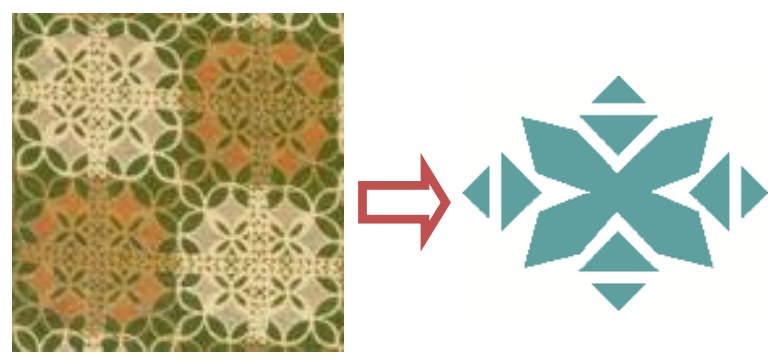

Gambar 7. Pengembangan ornamen binari kawung

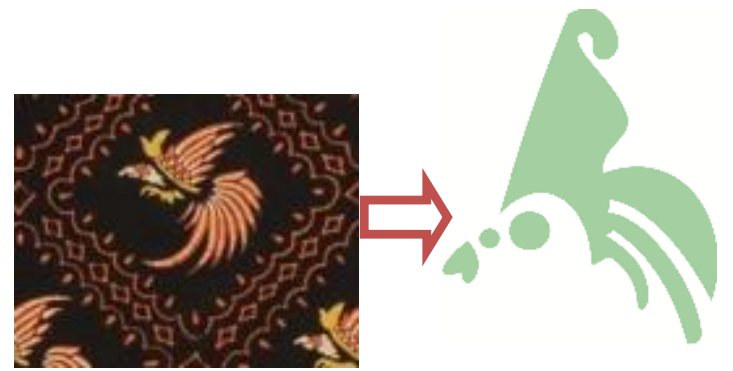

Gambar 8. Pengembangan ornamen jalak harupat

Hasil pengembangan ornamen tersebut diselaraskan dengan trend warna tahun 2015 sehingga menghasilkan beberapa rancangan motif kain tenun sebagai berikut :

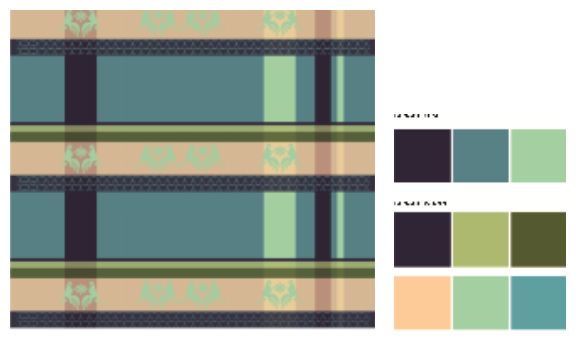

Gambar9. Desain kain tenun ATBM dobby1

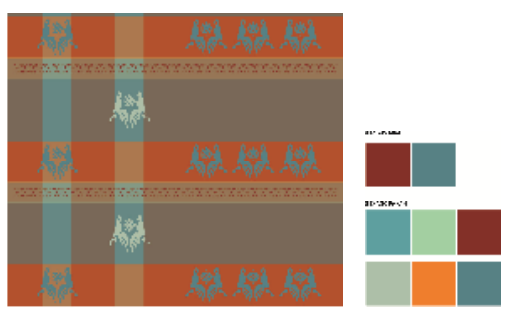

Gambar 10. Desain kain tenun ATBM dobby

\section{Hasil Pengujian}

Kain tenun ATBM dobby berasal dari benang lusi sebanyak $2 \mathrm{~kg}$ dan benang pakan 2 $\mathrm{kg}$ yang menghasilkan panjang kain $20 \mathrm{~m}$ dengan lebar kain $106,5 \mathrm{~cm}$. Pada kain tenun ATBM tersebut kekuatan tarik kain/ 2,5 cm, arah lusi adalah 260,0 Natau 26,5 kg dan arah pakan: 288,4 Natau 29,4 kg. Pada SNI 0051-2008, kekuatan tarik minimum adalah 107,9 $\mathrm{N}$ atau 11 $\mathrm{kg}$, maka dilihat dari standar tersebut, kekuatan tarik kain tenun ATBM yang dibuat sudah memenuhi standar.

Untuk kekuatan sobek, arah lusi adalah 47,1 Natau 4,8 $\mathrm{kg}$ dan arah pakan adalah 41,2 Natau 4,2 kg. Pada SNI, standar minimum kekuatan sobek adalah 6,9 Natau 4,8 kg, maka dilihat dari hasil akhir pengujian diatas, kain tenun ATBM ini telah memenuhi standar SNI 0051-2008. Hasil uji Kain ATBM yang dihasilkan dapat dilihat pada Tabel 1. 
Tabel 1. Data hasil uji fisika kain tenun ATBM dobby

\begin{tabular}{|c|c|c|}
\hline No & Jenis Uji & Hasil pengujian \\
\hline 1 & Lebar kain, m (inci) & $1,065(41,9)$ \\
\hline 2 & Berat kain, $\mathrm{g} / \mathrm{m}^{2}(\mathrm{~g} / \mathrm{m})$ & $114,8(122,3)$ \\
\hline 3 & Konstruksi: & \\
\hline 4 & Tetal lusi, hl/cm (hl/inci) & $28,7(73)$ \\
\hline 5 & Tetal pakan, hl/cm (hl/ inci) & $28,0(71)$ \\
\hline 6 & No. Benang Lusi, Tex (Ne1) & $9,2 \times 2(64,2 / 2)$ \\
\hline 7 & No. Benang Pakan, Tex (Ne1) & $9,8 \times 2(60,3 / 2)$ \\
\hline 8 & Anyaman & dobby \\
\hline \multirow[t]{3}{*}{9} & Kekuatan tarik kain/ $2,5 \mathrm{~cm}$ & \\
\hline & Arah lusi, N (kg) & $260,0(26,5)$ \\
\hline & Arah pakan, $\mathrm{N}(\mathrm{kg})$ & $288,4(29,4)$ \\
\hline \multirow[t]{3}{*}{10} & Mulur & \\
\hline & Arah lusi \% & 18,0 \\
\hline & Arah pakan \% & 8,1 \\
\hline \multirow[t]{3}{*}{11} & Kekuatan sobek Elemendorf & \\
\hline & Lusi, N (kg) & $47,1(4,8)$ \\
\hline & Pakan, N (kg) & $41,2(4,2)$ \\
\hline \multirow[t]{3}{*}{12} & Tahan kusut & \\
\hline & Lusi, $\left(\ldots . . .^{\circ}\right)$ & $66 / 72$ \\
\hline & Pakan, $\left(\ldots . . .^{\circ}\right)$ & $73 / 72$ \\
\hline 13 & Pilling box 3 jam & 4 \\
\hline 14 & Gosok Martindale s/d putus, gosokan & 10000 \\
\hline
\end{tabular}

Hasil uji kain secara kimia, mulai dari tahan luntur warna terhadap pencucian $40^{\circ} \mathrm{C}$, tahan keringat asam dan biasa, kain ini rata-rata berada di angka 4, 4-5. Namun pada hasil tahan gosok kering, nilai 4 untuk hasil yang baik dan pada tahan gosok basah, berada pada nilai 2-3 yaitu cukup baik. Dilihat dari hasil uji kimia, kain tersebut menandakan sudah baik dan memenuhi secara standar SNI untuk kain tenun sandang. Data hasil uji kimia kain tenun ATBM dobby dapat dilihat pada Tabel 2 .

Tabel 2. Data hasil uji kimia kain tenun ATBMdobby

\begin{tabular}{|l|c|c|c|c|c|}
\hline \multirow{2}{*}{ Jenis Uji } & \multicolumn{3}{|c|}{ Tahan Luntur Warna Terhadap } & \multicolumn{2}{c|}{ Tahan Gosok } \\
\cline { 2 - 6 } & Pencucian $40^{\circ} \mathrm{C}$ & Keringat Asam & Keringat Biasa & Kering & Basah \\
\hline Perubahan warna: & $4-5$ & $4-5$ & $4-5$ & 4 & $2-3$ \\
\hline Penodaan pada: & & & & & \\
- Kapas & 4 & $4-5$ & $4-5$ & & \\
- Wol & $4-5$ & $4-5$ & $4-5$ & & \\
\hline
\end{tabular}

Keterangan:

Nilai 1: Jelek, Nilai 2: Kurang baik, Nilai 3: Cukup baik, Nilai 4: Baik, Nilai 5: Sangat baik

Seperti diketahui bahwa di Jawa Barat khususnya Kota Bandung memiliki kain tradisional sarung yang umumnya menggunakan motif geometris. Pada penelitian ini telah dihasilkan kain tenun untuk kain sandang dengan motif geometris yang terlihat timbul karena berasal dari perbedaan warna benang yang atraktif. Bentuk motif kain yang ditampilkan lebih dititikberatkan pada motif geometris yang dikombinasikan dengan sistem dobby dan tenun ikat pakan.

Hasil kain jadi dari produk penelitian dengan menggunakan ATBM dobby, dapat dilihat seperti pada Gambar 11.

Dari hasil uji diatas, kain tenun ATBM ini mempunyai kualitas yang cukup baik dan dapat diterapkan oleh IKM pertenunan 

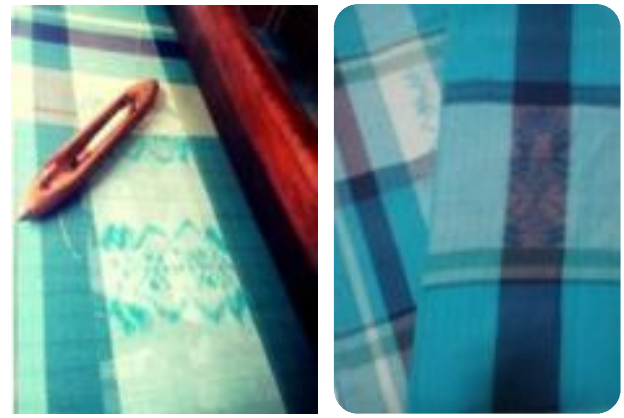

Gambar 11.Hasil kain tenun ATBM dobby dan ikat pakan

\section{KESIMPULAN}

Motif tradisional kain batik dapat dikembangkan ke dalam motif untuk kain tenun ATBM dobby dan ikat pakan yang dapat dikombinasikan secara bersamaan dalam satu kain tenun. Hasil pengujian pada kain ATBM menunjukkan bahwa nilai kekuatan tarik dan kekuatan sobek kain tenun ATBM yang dibuat telah memenuhi standar SNI 0051-2008. Dilihat dari hasil uji kimia, kain tersebut menandakan sudah baik dan memenuhi secara standar SNI 0051-2008. Kombinasi warna yang diambil dari trend warna 2015 dapat diaplikasikan kedalam satu desain kain tenun ATBM dobby dan ikat yang dibuat menjadi lebih modern dan dapat dipakai sebagai pakaian sehari-hari (casual outfit). Dilihat dari hasil pengujian baik benang maupun kain, sudah sesuai dengan standar SNI 0051-2008 dan dapat digunakan sebagai kain sandang.

Pengembangan dalam penelitian ini, baik dari segi pengembangan motif maupun kombinasi dua teknik pertenunan yaitu dobby dan ikat pakan, merupakan titik tolak untuk IKM Tekstil agar dapat mengembangkan teknologi pertenunan dalam pembuatan kain sandang, sehingga dapat menjadi nilai lebih suatu produk. Penelitian ini telah menghasilkan kain tenun ATBM dengan kualitas yang cukup baik dan motif yang atraktif, oleh karena itu dapat diterapkan oleh IKM khususnya IKM pertenunan.

\section{PUSTAKA}

${ }^{1}$ Sunaryo, A. (2009). Ornamen Nusantar: Kajian Khusus Tentang Ornamen Indonesia.Ed. 1., cet. 1, Dahara Prize, Semarang.
${ }^{2}$ Widodo, S.T.,Kusumawati, T., dan Rahadja, T., (2012). Pengembangan Industri Batik Kreatif Melalui Penciptaan Motif Batik Berbasis Seni Budaya Lokal dan Lingkungan Alam.Indonesian Science and Technology Digital Library, PDII LIPI.

${ }^{3}$ Suantara, D. (2014). Eksplorasi Desain Struktur Menggunakan Serat Alam Untuk Produk Kreatif. Laporan Akhir Penelitian dan Pengembangan, Balai Besar Tekstil, Bandung.

${ }^{4}$ Sunarya, Y.Y. (2013). Batik Digitalisasi Kreatif Motif Dalam Gaya Desain Dunia. Institut Teknologi Bandung

${ }^{5}$ Maryani, Sri., et al. (1998).Diversifikasi Produk Tenun Tradisional dengan ATBM Dobby. Laporan Akhir Proyek Pengembangan dan Pelayanan Teknologi Industri Tekstil, Bandung.

${ }^{6}$ Rachmatillah, Amira. (2015). Pengertian Ragam Hias, www.academia.edu, diakses 9 Oktober 2015.

${ }^{7}$ Gustami. (1980). Nukilan Seni Ornamen Indonesia, STSRI Yogyakarta.

${ }^{8}$ Read, Herbert. (1959). The Meaning of Art. Pinguin Books, London.

9 Davis, L. Marian. (1987). Visual Design in Dress, Prentice Hall Inc, Englewood Cliffs, New Jersey.

${ }^{10} \mathrm{https} / / /$ batiktiara.wordpress.com/2012/02/22. (2012), diakses 10 November 2015.

${ }^{11}$ Anonim. (2010). Balarea Batik Jabar, Batik Kota Bandung, diakses 12 Februari 2015.

${ }^{12}$ Wikipedia.org. (2013). Si Jalak Harupat, diakses 10 November 2015.

${ }^{13}$ Kartiwa, S. (1993). Tenun Ikat. Djambatan. Jakarta.

${ }^{14}$ Kusna, A, et al (2003): Pengembangan Desain Tenun Tradisional Ambon dengan Menggunakan ATBM Fungsi Ganda, Laporan Akhir Proyek Pengembangan dan Pelayanan Teknologi Industri Tekstil, Bandung.

${ }^{15}$ New York Fashion Week Color Forecasts. (2015). Spring 2015 Pantone Fashion Color www.pantone.com, diakses 9 Maret 2015.

${ }^{16}$ Standar Nasional Indonesia 0051-2008 : Kain Tenun Untuk Kemeja. Badan Standardisasi Nasional. 